\title{
Energy Systems Integration Implications for Public Policy
}

Cambini, Carlo; Congiu, Raffaele; Jamasb, Tooraj ; Llorca, Manuel ; Soroush, Golnoush

Document Version

Final published version

Publication date:

2020

License

CC BY-NC-ND

Citation for published version (APA):

Cambini, C., Congiu, R., Jamasb, T., Llorca, M., \& Soroush, G. (2020). Energy Systems Integration: Implications for Public Policy. Department of Economics. Copenhagen Business School. Working Paper / Department of Economics. Copenhagen Business School No. 2-2020CSEI Working Paper No. 2-2020

Link to publication in CBS Research Portal

\section{General rights}

Copyright and moral rights for the publications made accessible in the public portal are retained by the authors and/or other copyright owners and it is a condition of accessing publications that users recognise and abide by the legal requirements associated with these rights.

Take down policy

If you believe that this document breaches copyright please contact us (research.lib@cbs.dk) providing details, and we will remove access to the work immediately and investigate your claim. 
Copenhagen

Business School

HANDELSH ØJSKOLEN

\section{Department of Economics}

Copenhagen Business School

Working paper 2-2020

\section{Energy Systems Integration: Implications for Public Policy}

Carlo Cambini, Raffaele Congiu, Tooraj Jamasb, Manuel Llorca, Golnoush Soroush

Department of Economics - Porcelænshaven 16A, 1. DK-2000 Frederiksberg 


\section{WORKINIG PAPER}

Copenhagen School of Energy Infrastructure | CSEl

\section{Energy System Integration: Implications for Public Policy}

Carlo Cambini

Raffaele Congiu

Tooraj Jamasb

Manuel Llorca

Golnoush Soroush 


\title{
Energy Systems Integration:
}

\section{Implications for Public Policy ${ }^{*}$}

\author{
Carlo Cambini $^{a}$, Raffaele Congiu ${ }^{a}$, Tooraj Jamasb $^{b}$, Manuel Llorca $^{b}$, Golnoush Soroush $^{a}$ \\ ${ }^{a}$ Department of Management, Politecnico di Torino, Italy \\ ${ }^{\mathrm{b}}$ Copenhagen School of Energy Infrastructure (CSEI), Copenhagen Business School, Denmark
}

1 February 2020

\begin{abstract}
Energy Systems Integration (ESI) is an emerging paradigm and at the centre of the EU energy debate. ESI takes a holistic view of the electricity, gas and heat sectors to deliver a clean, reliable and affordable energy system. By identifying and exploiting the synergies within and between the sectors, ESI aims to increase flexibility in the energy system, maximize the integration of renewable energy and distributed generation, and reduce environmental impact. While ESI-enabling technologies have been studied from a technical perspective, the economic, regulatory and policy dimensions of ESI are yet to be analysed. This paper discusses ESI in a multi-step approach. We first focus on the economics of ESI-enabling technologies. We briefly discuss how the EU national regulators incentivise their adoption. We identify major economic and policy barriers to ESI and propose policy solutions to overcome these barriers. We conclude that current regulatory frameworks in the EU do not stimulate sufficient ESI investments and only through proper design of incentives the ESI paradigm could be achieved.
\end{abstract}

Keywords: energy systems integration; sector coupling; regulation; innovation; research and development; economic and policy barriers.

JEL classification: L51, L94, Q4.

*Carlo Cambini, Raffaele Congiu and Golnoush Soroush gratefully acknowledge EU's H2020 research and innovation project PLANET (Planning and operational tools for optimizing energy flows and synergies between energy networks), Grant Agreement No. 773839. Tooraj Jamasb and Manuel Llorca acknowledge the funding from the Engineering and Physical Sciences Research Council (EPSRC) through the National Centre for Energy Systems Integration (EP/P001173/1). 


\section{Introduction}

Climate change concerns are transforming the energy industry from technical, economic, and political viewpoints. For centuries, fossil fuels have been considered as the main sources of energy due to their cost advantage and high energy contents. The energy and transportation sectors have mostly depended on fossil fuels (IEA, 2018). Hence, the focus of policy makers has been directed towards decarbonisation of these sectors. In the light of the rapid technological developments in clean energy resources, the transition towards a zero-carbon energy industry is now plausible. Technological advances have considerably lowered the cost of distributed generators that use Renewable Energy Sources (RES) such as wind and solar energy and demand side solutions.

As a result of lower costs and policy support, deployment of RES has become a focal point of the EU's agenda and is boosted at industry and household levels. Although this trend can lead to economic and environmental benefits, it also imposes a challenge on the energy sector. For instance, integration of RES and Distributed Generation (DG) capacity will lead to higher operational and capital expenditures in transmission and distribution networks (de Joode et al., 2009; Cossent et al., 2009, 2011; Lo Schiavo et al., 2013). Moreover, economic and regulatory aspects of integrating DG into the electricity network (and recently, heat network) still need to be revised and improved (Jenkins and Pérez-Arriaga, 2017; Cambini, 2016; Peças Lopes et al., 2007; Strbac, 2002; de Joode et al., 2010).

As decarbonisation policies push towards further adoption of RES generation, there is a need for an approach that allows simultaneous streamlining of DG integration while providing a sustainable and reliable energy system. Energy Systems Integration (ESI), by taking a holistic view of energy systems and utilising the synergies between them, can reduce the investments required to address the shift towards a renewable energy system with respect to a scenario in which investment planning is made separately for each different energy network.

Sector coupling or integration is recognised as a strategic means to achieve the first climateneutral continent by 2050 in the new European Green Deal signed by the European Commission and supported by the European Parliament in January 2020. The key role of ESI in the EU's future energy sector is evidenced by the Ten-Year Network Development Plan (TYNDP) jointly prepared by the European Network of Transmission System Operators for Electricity (ENTSO-E) and the European Network of Transmission System Operators for Gas (ENTSOG) (ENTSO-E and ENTSOG, 2019). The scenarios described in the TYNDP will be used in Cost- 
Benefit Analysis (CBA) to identify European transmission and storage infrastructure projects that are crucial for the development of the European energy market integration.

ESI benefits from technological developments in the information and communication sector as well as in energy storage systems (ESS) and conversion technologies to improve flexibility and reliability of energy systems while reducing the overall costs. In addition to technical developments, implementing ESI will require a coordinated development of policies and regulatory frameworks. However, the existing literature has almost exclusively addressed ESI from technological and business-model dimensions.

This paper recognizes the importance of these aspects and provides an economic overview of the abovementioned technologies as well as their role within an integrated energy system. The case for ESI stems from the economics of the energy sector and the relevance of technology lies in its ability to shape and affect them. Regulation has a role in guiding this process, while overcoming the barriers emerging from the structure of the industry. For this to be achieved, regulation needs to keep up with technological progress and the evolving needs of the energy system. This subject, contrary to technical aspects of ESI, has not been explored adequately in the literature. The main contribution of this study is to identify and discuss regulatory and policy barriers towards the attainment of ESI and make recommendations to overcome these barriers.

The remainder of the paper is as follows. Section 2 discusses the concept of ESI. Section 3 is an overview of the technologies that facilitate implementation of ESI. Section 4 presents an overview of conventional and most recent regulatory frameworks with respect to their approach towards innovation. Section 5 reviews the state of efforts in four major EU countries to foster network innovation, from a regulatory and investment perspective. We then identify and analyse economic and regulatory barriers towards ESI implementation in Section 6. Section 7 discusses policy implications and presents conclusions.

\section{Energy Systems Integration}

ESI is an emerging paradigm which proposes a holistic view of the energy systems, rather than a perspective based on single segments (i.e., generation, transmission, distribution, retail) within a specific sector (i.e., electricity, gas, heat). The goal is to reduce total system costs while contributing to achieve a clean, affordable and secure energy system. The rationale behind ESI is the existence of synergies within and between energy sectors that can achieve efficiency 
gains. Their existence is attributable to vertical and horizontal economies of scope and to the possibility of lowering transaction costs between grid users. While some of these synergies have always characterized the structure of the energy system, others are now emerging due to technological progress.

The reforms that started in 1990s led to unbundling of previously vertically-integrated utilities and to split them into competitive and regulated segments. As a result, transmission and distribution sectors are subject to economic regulation to maximise social welfare. ${ }^{1}$ As discussed by Jamasb and Llorca (2019), prior to the reforms the vertical structure of network utilities enabled them to benefit from economies of scope. Gugler et al. (2017) estimates the cost savings due to vertical integration of transmission and generation in medium-sized utilities to be about $13 \%$, with higher cost savings for larger firms. This cost saving was the result of common usage of inputs and of information and risk sharing (Gugler et al., 2017). The rationale for unbundling was to exert competitive pressure on generation and retail segments, deeming that this positive effect would offset the synergies loss.

In recent years, the energy sector has rapidly changed from being purely efficiency-oriented to also emphasizing environmental sustainability. EU countries committed to cut $\mathrm{CO}_{2}$ emissions to address climate change concerns, which led to the adoption of large-scale RES generation and a transformation from a centralised generation and unidirectional power flows to one of distributed generation and bidirectional power flows. This transformation carries new challenges, mainly attributable to non-dispatchability of renewables due to their intermittent nature. This makes it harder to balance electricity demand and supply. When peaks in electricity production occur and the load cannot follow generation, curtailment of generators becomes necessary, while the use of conventional backup capacity (e.g., fossil fuels) is needed in the opposite scenario. DNV GL (2014) estimated that - without further investments in network capacity - more than 100 TWh of renewable energy will be curtailed per year by 2030. Costefficient integration of RES thus requires substantial investments in infrastructure for network expansion and for the installation of backup generation.

Although the need for investments cannot be avoided, regulators across Europe recognize that system flexibility can help achieve a cost-efficient outcome. ${ }^{2}$ While traditionally flexibility has been achieved by matching generation to demand, new technologies offer flexibility by

\footnotetext{
${ }^{1}$ These sectors possess natural monopoly characteristics and therefore are required to be regulated.

2 Ofgem defines flexibility as "modifying generation and/or consumption patterns in reaction to an external signal (such as a change in price) to provide a service within the energy system” (Ofgem, 2019, para. 4).
} 
targeting both supply and demand. Demand Response (DR) can help consumers through price signals and match demand and supply. Energy storage - such as Electric Batteries (EBs) and Plug-in Electric Vehicles (PEVs) - and conversion systems - such as Combined Heat and Power (CHP) or Power to Gas (P2G) - allow storing energy when production exceeds demand. DG can help minimize transport costs and network losses by consuming energy closer to where it is produced. These technologies exploit synergies within and across energy sectors by enhancing coordination among stakeholders.

In order to identify and exploit these synergies there is a need for a comprehensive outlook that encompasses all energy systems. Current discussions on viewing electricity distribution and transmission networks as a whole suggest that treating these networks with a whole system approach $^{3}$ (CEER, 2018) can provide further reliability and efficiency to the electricity network. However, this approach does not allow taking advantage of the synergies that exist between different energy systems since the focus is on the electricity sector. The ESI paradigm looks at how economies of scope and coordination as well as the synergies between different energy networks, including electricity, gas and heat, can provide an energy system that is clean, secure and affordable.

Error! Reference source not found. shows an integrated electricity, gas and heat energy system. With enabling technologies such as storage and conversion systems acting as the interfaces between networks, integration of energy networks can occur both at horizontal and vertical level. This integration can be organizational, operational or physical, and it can involve different stakeholders (generators, network operators, retailers, consumers) within and across sectors. More specifically:

- From an organizational point of view, it implies a bundling of activities, previously performed by different parties, under a single entity, to take advantage of economies of scope. An example at vertical level is distributed generation, under which consumer and generator coincide. At horizontal level, this could result in the emergence of multiutilities or of generators that operate in different markets. ${ }^{4}$

\footnotetext{
${ }^{3}$ Through a Whole System Approach (WSA), Distribution System Operators (DSOs) are required to take into account the benefits of other DSOs and Transmission System Operators (TSOs) when they plan their investments. This will require improved coordination between DSOs and TSOs as well as a holistic view of the electricity network rather than focusing on one segment (CEER, 2018).

${ }^{4}$ As in Germany, Italy, Denmark and Slovenia through CHP.
} 
- From an operational point of view, it works by providing interfaces that help lower transaction costs and increase coordination between operators. An example at vertical level is the use of EBs to offer ancillary services. At horizontal level, we could have flexibility providers which use conversion technologies as P2G.

- From a physical point of view, it can mean cross-sectoral infrastructure planning (such as the scenarios described by the TYNDP), in order to reduce total investment and operating costs.

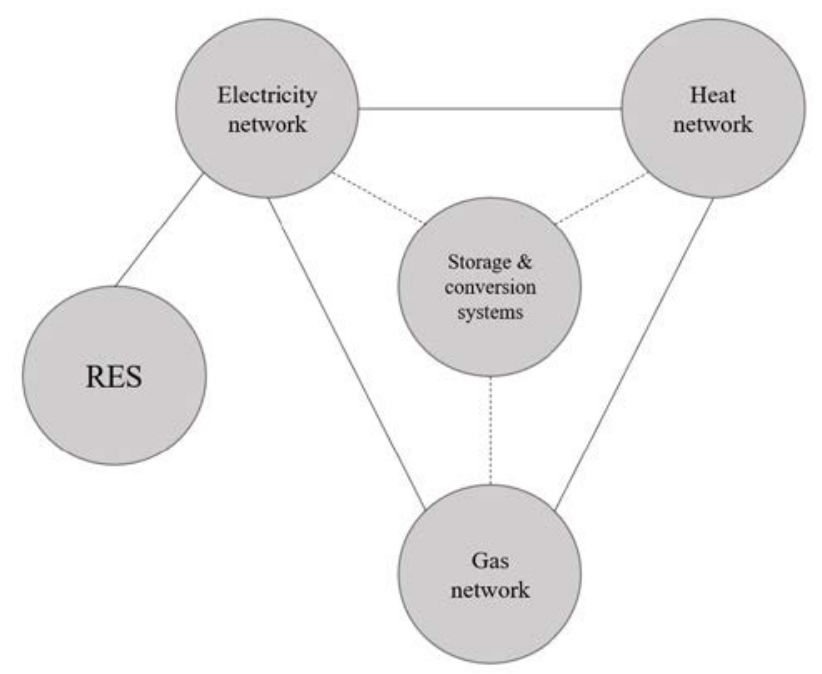

Figure 1: Integration between the energy networks

ESI is a combination of different types of integration. Due to the wide scope of ESI solutions, there is no specific single or optimal solution that can be recommended when adopting it. In fact, energy systems are idiosyncratic: path dependency and the need to consider local concerns, resource base, and political agendas are likely to cause each country - and even different regions of a country - to require different ESI solutions. There is therefore a need for a bespoke approach that takes into consideration these peculiarities and provides a context-specific framework. Furthermore, Jamasb and Llorca (2019) point that ESI needs to coevolve with the energy system.

As in the case of RES generation and DG, technological progress can lead to changes in the structure of the energy industry, the appearance of new players and the emergence of new opportunities. Moreover, the boundary between markets and regulation is not fixed; although technological advances can shift its position, regulators also have a role in deciding it (Jamasb and Llorca, 2019). ESI needs to be able to recognize these changes in order to find and exploit new synergies were they to occur. 


\section{Technologies for ESI}

The important role of integrated technologies is recognized in the literature. Badami and Fambri (2019) propose a methodological approach for analysing the synergies between different energy networks to cope with increasing RES penetration by use of flexibility-enhancing technologies. Brown et al. (2018) propose a cross-sector and cross-border energy model of Europe to estimate the economic effect of flexibility options (energy conversion and storage) and cross-border transmission in a scenario where $\mathrm{CO}_{2}$ emissions are reduced by $95 \%$ with respect to 1990 levels. They find that the flexibility option leads to a reduction in total system costs of $28 \%$, while cross-border transmission system cost saving is equal to $25 \%$.

Rather than analysing these technologies from a technical viewpoint, this section discusses the role they can play in ESI, their economic dimension, and their economic impact. We classify these technologies under Information and Communication Technology (ICT), storage systems and conversion technologies.

\subsection{Information and Communication Technology}

ICT transforms the way energy networks interact with each other and with other network industries, such as the telecommunication and transportation sectors. Rapid technological development in the ICT sector facilitates the transition towards a low carbon energy system as well as the exploitation of the synergies that exist within and between energy systems. In fact, it is through ICT that grid user coordination, active participation of consumers, smart network management and synchronization between multiple energy networks become possible.

ICT is a core component of ESI, as it allows collection of generation and consumption data that can be used to balance supply and demand within a network and to enhance stability of the energy system. In addition, ICT facilitates the coordination and data exchanges within and between energy networks, which leads to lower transaction costs and more efficient network management. Furthermore, a better synchronized energy system enables the use of conversion technologies and allows a price-driven choice of the energy mix, which enhances affordability of the system as a whole. This, together with information transparency provided by ICT, can increase the competition and emergence of new business models in the energy industry (Jamasb and Llorca, 2019). 
Improved communication between grid users is required to facilitate integration of $\mathrm{DR},{ }^{5} \mathrm{DG}$, and, more recently, ESS and PEVs. DR and DG, in particular, are recognized by the EU in article 14/7 2003/54/EC of the electricity directive and later in Directive 2009/72/EC to be an alternative to construction of new network capacity that is required to meet additional demand. In electricity networks, communication between grid users is carried out through Smart Grids (SGs). ${ }^{6}$ The diffusion of SGs in the EU has been analysed in detail by Cambini et al. (2016a). The study investigates the regulatory factors affecting SG investments in Europe using a dataset of 459 innovative SG projects. They show that incentive-based regulatory schemes and the adoption of innovation-stimulus mechanisms are key enablers of SG investments.

\subsection{Energy Storage Technologies}

Energy storage can be provided through several technologies. Pumped Hydro Storage (PHS) is currently the most utilised storage mechanism ${ }^{7}$ with a capacity equal to $3 \%$ of the global generation capacity (Ameli et al., 2017). Nevertheless, recent years have seen the emergence of alternative technologies, mainly in the form of EBs. Storage systems in suitable parts of the value chain can help to decouple supply and demand of energy. In addition, intermittent sources of energy can be integrated more efficiently, which in turn can improve flexibility and reliability of the energy system. Jamasb (2017) points out that storage technologies differ in size and type of services they can offer from very short-term reliability services to medium-term energy supplies.

ITRE (2015) suggests that operation of storage systems can be classified as network- or marketoriented, depending on whether, respectively, network operators or end-users are the beneficiaries. By using storage services, the RES feed-in is managed more efficiently. Network operators can store the excess feed-in when the demand is low and utilize it when a peak in

\footnotetext{
${ }^{5} \mathrm{DR}$ aims at changing the shape of the load curve by allowing consumers to change their consumption behaviour through price signals. Deployment of DR requires advanced metering infrastructures, which are currently being rolled out in the EU countries and are expected to be available to over 70\% of customers by 2020. DNV GL (2014) estimates that more effective use of DR in the EU can lead to annual savings of between $€ 60$ and $€ 100$ billion. In addition, it allows consumers to become active network users and enjoy financial benefits by adjusting their consumption in response to changes in the energy price.

${ }^{6}$ The European Commission defines a smart grid as "an electricity network that can cost efficiently integrate the behaviour and actions of all users connected to it - generators, consumers and those that do both - in order to ensure economically efficient, sustainable power system with low losses and high levels of quality and security of supply and safety" (EC Directorate-General for Energy, 2011, p.2).

${ }^{7}$ According to the World Energy Council, PHS accounts for over 95\% of today's energy storage (World Energy Council, 2016).
} 
demand occurs (ITRE, 2015). In addition, operators can use data acquired through smart meters to reduce network congestion and decide about further network expansions considering their storage capacities (Leuthold, 2015). Transmission operators can use storage systems to balance voltage and frequency and stabilize the grid.

$\mathrm{Li}$ and Hedman (2015) analyse the economic impact of energy storage systems on the cost of conventional generators in a scenario of high penetration of renewable resources. They show that with deployment of storage technologies in power systems with high penetration of RES, the hourly average costs for conventional generation is lower. They conclude that storage systems can reduce the need for conventional generators, which in turn will lower system total costs.

Traditional consumers, ${ }^{8}$ by using SGs and the price signals they receive from retail markets, can decide whether to go off-grid and use private storage or electric vehicles as a form of smallscale storage system, or to stay connected to the grid. ESS can be particularly beneficial to prosumers. Where regulation allows it, prosumers can store their excess electricity production and self-consume ${ }^{9}$ it later on to avoid both high volume-based and capacity-based tariffs. ${ }^{10}$ Technological progress in consumer electronics and - more recently - of electric mobility, is making this storage solution considerably cheaper (Bloomberg New Energy Finance, 2018).

Deployment of EBs requires large capital expenditure (Atherton et al., 2017), which is the main barrier to the adoption of these technologies (Sandia, 2013). High capital cost reduces competitiveness of EBs with respect to other solutions that offer flexibility to the grid. Ameli et al. (2017) assess the impact of EBs on the operating cost of gas and electricity systems in Great Britain. Their results indicate that EBs can significantly reduce the operating costs of both systems. However, they argue that EBs are highly capital-intensive and investing in them is only feasible when the capital cost is below $£ 0.4 \mathrm{~m} / \mathrm{MW}$ (and 2 MWh storage capacity). Despite their high capital costs, system benefits of EBs could compensate for the high investments (Ameli et al., 2017). Moreover, the cost of EBs is in sharp decline. There has been a reduction of almost 80\% from 2010 to 2017 (Bloomberg New Energy Finance, 2018). Thus,

\footnotetext{
${ }^{8}$ By traditional consumers we refer to users who have not installed small-scale DG such as Photovoltaic (PV) systems and depend entirely on the grid for their electricity demand.

${ }^{9}$ Storage could increase the percentage of self-consumption of locally produced power from some $30 \%$ to $65-75 \%$ for households (EC, 2015).

${ }^{10}$ For peak load shaving purposes, capacity-based network tariffs can be used as an incentive to encourage selfconsumption and use of storage by prosumers.
} 
other flexibility-offering technologies could be seen as a complement rather than a substitute to EBs to provide extra benefits to the energy systems.

Another emerging storage technology is PEVs. The expected high penetration of PEVs, with possible use as a storage solution in the Vehicle to Grid (V2G) paradigm, has led to a growing interest in the potential of distributed storage solutions. The diffusion of PEVs and the electrification of the transport sector will have major consequences for the energy system. Under the assumption of bidirectional flows within a V2G paradigm, a scenario of high penetration of PEVs would in fact imply a high amount of distributed storage systems, which at times could work as a load, at times as a generator. However, Fernandez et al. (2011) point out that PEVs' overall contribution will be an increase in consumption, thus requiring an upgrade to the distribution network in order to make the charging possible. Their results show that, in a scenario with $60 \% \mathrm{EV}$ penetration and depending on the charging strategies, investment costs for distribution operators could increase up to $15 \%$, and energy losses in offpeak hours could increase up to $40 \%$.

\subsection{Conversion Systems}

Conversion technologies can increase the flexibility of the energy systems. They increase the degree of substitutability between energy sources and allow to decouple demand and supply by converting electricity into other energy sources which can then be consumed at a later moment, thus acting as a form of storage. This can lead to more affordable energy systems, as the need for backup generation capacity is reduced and end users can choose their energy mix in a more efficient way based on energy market prices.

While conversion systems are promising, their adoption will depend on whether technological progress can overcome two barriers: the required investments and conversion efficiency. We focus on some already adopted technologies, such as Combined Heat and Power (CHP) and local power or gas to heat, and some emerging ones, such as Power to Gas (P2G). CHP allows product electricity and heat from gas, while providing significant energy savings (up to 40\%) and high conversion efficiency (60-85\% depending on the power to heat ratio) (Brodecki et al., 2014). This technology is widely adopted in the EU, covering $11 \%$ of total electricity generation (Eurostat, 2019). The International Energy Agency (IEA) estimates that increased use of CHP 
can reduce investments in the power sector while cutting $\mathrm{CO}_{2}$ emissions, leading to a reduction in global power sector capital cost of 7\% by 2030 (Kerr, 2008).

When located close to final users, CHP can be used in District Heating (DH) networks to minimize inefficiencies by producing power and heat generation on site. This limits network losses while using the residual heat that would be wasted by traditional thermal plants. Colmenar-Santos et al. (2016) assess the implications of substituting conventional thermal plants with CHP coupled with DH networks in the EU. They find that with an annual investment of $€ 300$ billion, a reduction in fuel expenses of $€ 100$ billion per year and a $15 \%$ reduction of the final energy consumption can be achieved. These figures reflect the efficient but capitalintensive feature of the technology.

Local power/gas to heat are referred to traditional and hybrid heat pumps, electric heaters, gas boilers, and all other small-scale conversion technologies which can provide heating and cooling in the absence of $\mathrm{DH}$. The aggregation and coordination of the loads of these appliances through SGs and DR programmes can act as a form of virtual energy storage, increasing flexibility and providing ancillary services to the networks (Martin Almenta et al., 2016, Cheng et al., 2017). Furthermore, the presence of hybrid appliances such as hybrid heat pumps allows end-users to make efficient choices regarding the source of energy, considering price and technical aspects (e.g., outdoor temperature).

P2G allows the conversion of electricity into hydrogen or synthetic natural gas (methane). This technology could bring high flexibility to the energy system by absorbing the excess production of RES that would otherwise be curtailed when demand is low. This energy could be stored as gas for later consumption at peak demand times. P2G can play an important role for the integration of RES, since gas is easier to transport and store than electricity, and it offers the largest long-term energy storage capacity.

Although a variety of pilot projects are being run, this technology has yet to see adoption. Several technical studies have assessed cost-efficiency of P2G, with sometimes contradictory results. Baumann et al. (2013) and Budny et al. (2015) show that P2G is not economically viable at present and could remain so in the near future. Budny et al. (2015) state that, for P2G to be viable, high feed-in tariffs of $€ 100$ per MW for hydrogen and $€ 130$ per MW for methane would be needed. Schiebahn et al. (2015) point out how renewable hydrogen, as a fuel for fuel cell electric vehicles, could make P2G cost-efficient. Adoption of P2G will ultimately depend on 
further progress to increase efficiency and reduce capital expenditures, and on the relative price of electricity with respect to hydrogen and methane.

As it can be seen, techno-economic studies suggest that the above discussed technologies can provide benefits to various parts of the energy systems either through cost savings or by providing flexibility options. However, the literature also suggests that these technologies are, in general, still expensive. Their development requires either large investments by end-users and/or large-scale service providers to operate them or large investments by system operators to accommodate them into the networks. In this context, regulation can play a relevant role to incentivize adoption of these new technologies. Since TSOs and DSOs are regulated firms, whether they invest in innovative technologies or eventually adopt them, is directly impacted by regulations and policies in place regarding innovation.

\section{Role of Economic Regulation in ESI}

The main pillar of any ESI scheme is new technologies and innovative projects. While, as mentioned in Section 3, new technologies assist in achieving social objectives, by nature, innovation is both costly and risky. In this context, regulation should encourage network operators to increase their investment in $R \& D$ projects by providing them proper monetary incentives. However, since the reforms of 1990s and the liberalization of the energy networks, the regulatory efforts have been focused on improving efficiency of the utilities as well as improving service quality rather than stimulating innovation (Müller, 2011; Meeus and Saguan, 2011; Agrell and Bogetoft, 2011; Joskow, 2014; Cambini et al., 2016b). As a result, regulatory approaches tend to place emphasis on the reduction of operational costs to achieve efficiency while allowing the pass-through of capital expenditures.

Although cost of innovation in the electricity sector is considerably high, investments in conventional technologies are considered to be more capital-intensive. Thus, under a regulatory scheme that allows the pass-through of capital costs, utilities tend to invest in more capitalintensive solutions (Meeus and Saguan, 2011) rather than less costly but risky innovative technologies. Nykamp et al. (2012) and Prüggler and Bremberger (2011) show how such an outcome is currently observable in Germany and Austria.

Furthermore, the uncertainty regarding the successful outcome of any kind of innovation or $R \& D$ activity is an obstacle that forces utilities to act with caution when deciding to invest in 
new technologies, including the ones enabling ESI. In this regard, development and adoption of innovative technologies require support from policy makers as well as sound regulatory frameworks that provide monetary incentives for the firms to stimulate innovation.

In practice, standard regulatory approaches such as cost of service (rate-of-return) and fixedprice (incentive) regulations do not provide utilities enough incentives to invest in innovative projects (Bauknecht, 2011). As these conventional regulatory approaches fail to provide incentives for innovation and investment in energy networks, innovative regulatory frameworks should be developed. So far, the solution has been to devise hybrid regulatory frameworks that take a different approach towards $\mathrm{R} \& \mathrm{D}$ costs compared to the other operational network expenditures (Bauknehcht and Brunekreeft, 2008). Bauknecht (2011) discusses in detail innovative regulatory approaches towards innovation, including input-based and output-based incentive mechanisms as well as hybrid approaches which are a combination of conventional regulatory frameworks.

In particular, output-based mechanisms are relatively new in regulation of energy utilities. They focus on improving the performance of the utilities with regards to the quality of their services as well as the desired sustainability targets. Regarding innovation, in contrast to input-based mechanisms, which focus on minimizing production costs, output-based mechanisms focus on the outcome of innovation (Bauknecht, 2011). However, defining the outputs to be incentivized is complex and requires detailed information regarding the outcomes of the innovative projects as well as extensive budget and skills on the regulator's side (Glachant et al., 2012).

Although output-based mechanisms are successful in encouraging the utilities to increase investment in innovative solutions, defining what can be considered as innovation is as hard as separating the cost of innovation from other costs in the input-based mechanisms. Therefore, designing a regulatory framework which is both reliable in promoting innovation and easy to implement will be a challenging endeavour for regulators. For this reason, regulatory authorities around the world decide to apply a combination of these mechanisms to achieve their goals of prompting innovation in the energy networks as well as improving the overall efficiency of these networks. 


\section{Evidence from Selected EU Countries}

In the previous sections we emphasized the importance of technological and regulatory solutions to achieve ESI. In this section we provide a summary of the regulatory frameworks that are being used around Europe to foster network innovation (including ESI). In particular, we look at the regulatory schemes in the United Kingdom, Germany, France and Italy, with a focus on the incentives they provide for adoption of innovative solutions in electricity and gas sectors. Error! Reference source not found. summarizes the current regulatory scenario in those countries.

Table 1: An overview of policies to foster network innovation of four EU countries.

\begin{tabular}{|c|c|c|c|c|}
\hline & United Kingdom & Germany & France & Italy \\
\hline $\begin{array}{l}\text { Type of } \\
\text { regulation }\end{array}$ & $\begin{array}{l}\text { Revenue cap with } \\
\text { output, efficiency } \\
\text { and innovation } \\
\text { incentives }\end{array}$ & $\begin{array}{l}\text { Revenue cap with } \\
\text { expansion incentives }\end{array}$ & $\begin{array}{l}\text { Hybrid: revenue cap } \\
\text { with cost of service } \\
\text { elements. Efficiency } \\
\text { incentives }\end{array}$ & $\begin{array}{l}\text { Hybrid: revenue cap } \\
\text { with cost of service } \\
\text { elements. Efficiency } \\
\text { incentives }\end{array}$ \\
\hline $\begin{array}{l}\text { Regulatory period } \\
\text { length }\end{array}$ & 8 years & 5 years & 4 years & $\begin{array}{l}8 \text { years (electricity), } \\
4 \text { years (gas) }\end{array}$ \\
\hline $\begin{array}{l}\text { Innovation } \\
\text { incentives }\end{array}$ & $\begin{array}{l}\text { Innovation stimulus } \\
\text { packages: } \\
\text { adjustments to } \\
\text { revenue allowance } \\
\text { and competition for } \\
\text { funding }\end{array}$ & $\begin{array}{l}50 \% \text { cost recovery } \\
\text { for innovative } \\
\text { projects that fall } \\
\text { under ministerial } \\
\text { funding programmes }\end{array}$ & $\begin{array}{l}\text { Full cost recovery } \\
\text { for innovative } \\
\text { projects approved by } \\
\text { the regulator }\end{array}$ & $\begin{array}{l}\text { WACC mark-up for } \\
\text { innovative projects }\end{array}$ \\
\hline $\begin{array}{l}\text { Costs added to } \\
\text { RAB (Regulatory } \\
\text { Asset Base) }\end{array}$ & Capex and Opex & Capex and Opex & Capex & Capex \\
\hline $\begin{array}{l}\text { Innovation } \\
\text { funding }\end{array}$ & Regulation-based & $\begin{array}{l}\text { Government-based: } \\
\text { grants given under } \\
\text { ministerial funding } \\
\text { programmes }\end{array}$ & $\begin{array}{l}\text { Hybrid: regulation, } \\
\text { government and EU- } \\
\text { based }\end{array}$ & $\begin{array}{l}\text { Hybrid: regulation, } \\
\text { government and EU- } \\
\text { based }\end{array}$ \\
\hline
\end{tabular}

The UK has been the most proactive country in fostering innovation through regulation through its RIIO (Ofgem, 2010) regulatory framework. RIIO offers an innovation stimulus for each network, consisting of three measures: the Network Innovation Allowance (NIA) ${ }^{11}$ the

\footnotetext{
${ }^{11}$ The NIA is an annual allowance for network licensees to fund small R\&D and demonstration projects. This allowance is added to the base revenue when determining the annual amount that the licensee can recover from its customers. The Authority decides on the project approval only on special circumstances, otherwise it is automatic once it is disclosed through an appropriate website. Up to 2017, about £60m were made available annually through the NIA (Ofgem, 2017).
} 
Network Innovation Competition (NIC), ${ }^{12}$ and the Innovation Roll-out Mechanism (IRM). In order to provide an insight on the quantitative impact of the innovation stimuli, we categorized - based on the technological domain - the projects that started between RIIO’s introduction in 2013 and September 2018, with a budget over $£ 1$ million and which have been financed under NIA and NIC. The 118 projects make up for almost $75 \%$ of the overall NIA and NIC budgets. Seven categories have been used, with each project being assigned to a single category - the most relevant one - even in the case in which its scope would encompass more than one. The findings are reported in Error! Reference source not found.. ${ }^{13}$

Table 2: Classification of UK's NIC and NIA projects (above $£ 1$ million budget).

\begin{tabular}{|l|c|c|c|}
\hline \multicolumn{1}{|c|}{ Category } & $\begin{array}{c}\text { No. } \\
\text { Projects }\end{array}$ & $\begin{array}{c}\text { Budget } \\
(\mathbf{E m )}\end{array}$ & $\begin{array}{c}\text { Avg. } \\
\text { Budget } \\
(\mathbf{E m )}\end{array}$ \\
\hline Network Management $^{14}$ & 62 & 325.4 & 5.2 \\
\hline Low carbon technologies and energy efficiency & 7 & 56.1 & 8.0 \\
\hline EV and hydrogen vehicles & 5 & 11.0 & 2.2 \\
\hline Smart Grids & 13 & 65.5 & 5.0 \\
\hline Storage systems & 2 & 2.9 & 1.4 \\
\hline Energy systems integration & 1 & 5.2 & 5.2 \\
\hline Others & 28 & 85.9 & 3.1 \\
\hline Total & $\mathbf{1 1 8}$ & $\mathbf{5 5 2 . 1}$ & $\mathbf{4 . 7}$ \\
\hline
\end{tabular}

Source: Elaboration on data available from Smarter Networks portal.

Innovation in the UK has been mainly regulation-driven. However, the other countries examined have taken different approaches. In Germany incentives to R\&D and adoption of new technologies are mainly provided under large ministerial programmes funded by the Federal Government to reflect the national energy policy (BMWi, 2018), leaving the regulator with a limited role in this regard. France and Italy, on the other hand, have taken a hybrid approach:

\footnotetext{
12 The NIC is an annual competitive process run to finance a selected amount of large development and demonstration projects. For each sector, transmission and distribution operators compete for funding. NIC provides up to $£ 70 \mathrm{~m}$ per year for electricity networks and $£ 20 \mathrm{~m}$ per year for gas networks and funds up to $90 \%$ of a project's total budget, forcing operators to bear some of its cost (Ofgem, 2017). Up to September 2018, about £200m have been granted.

${ }^{13}$ Network operators have the obligation to disclose data on NIC and NIA projects on the Smarter Networks portal to help disseminate knowledge. The portal can be reached at http://www.smarternetworks.org/.

${ }^{14}$ This category comprises technologies that improve network reliability, control, safety, and service quality.
} 
incentives are provided through adjustments in revenue allowances granted by the regulator as well as grants given under EU and National programmes. Table 3 categorizes network innovation projects being performed in these countries by TSOs and DSOs as well as their funding resources and allocated budgets. ${ }^{15}$

Table 3: Overview of network innovation projects in Germany, France and Italy.

\begin{tabular}{|c|c|c|c|c|c|c|c|c|c|}
\hline Country & \multicolumn{3}{|c|}{ Germany } & \multicolumn{3}{|c|}{ France } & \multicolumn{3}{|c|}{ Italy } \\
\hline $\begin{array}{l}\text { Project } \\
\text { category }\end{array}$ & $\begin{array}{l}\text { Source of } \\
\text { funding }\end{array}$ & $\begin{array}{c}\text { Total } \\
\text { budget }\end{array}$ & $\begin{array}{c}\text { Main } \\
\text { stakeholders }\end{array}$ & $\begin{array}{l}\text { Source of } \\
\text { funding }\end{array}$ & $\begin{array}{l}\text { Total } \\
\text { budget }\end{array}$ & $\begin{array}{c}\text { Main } \\
\text { stakeholders }\end{array}$ & $\begin{array}{c}\text { Source of } \\
\text { funding }\end{array}$ & $\begin{array}{c}\text { Total } \\
\text { budget }\end{array}$ & $\begin{array}{c}\text { Main } \\
\text { stakeholde } \\
\text { rs }\end{array}$ \\
\hline \multirow{2}{*}{$\begin{array}{l}\text { Smart } \\
\text { Grids }\end{array}$} & \multirow{2}{*}{$\begin{array}{l}\text { National } \\
\text { and private } \\
\text { funds }\end{array}$} & \multirow{2}{*}{$\begin{array}{l}€ 600 \\
\text { millions }\end{array}$} & \multirow{2}{*}{$\begin{array}{l}\text { TSO and } \\
\text { DSO }\end{array}$} & \multirow{2}{*}{$\begin{array}{l}\text { EU and } \\
\text { national } \\
\text { funds and } \\
\text { increase } \\
\text { in } \\
\text { network } \\
\text { tariffs }\end{array}$} & \multirow{2}{*}{$\begin{array}{l}€ 832 \\
\text { million }\end{array}$} & \multirow{2}{*}{$\begin{array}{l}\text { TSO and } \\
\text { DSO }\end{array}$} & $\begin{array}{l}\text { Increase } \\
\text { in } \\
\text { network } \\
\text { tariffs } \\
(+2 \% \\
\text { WACC } \\
\text { for } 12 \\
\text { years })\end{array}$ & $\begin{array}{l}\text { €17.4 } \\
\text { million }\end{array}$ & DSO \\
\hline & & & & & & & $\begin{array}{l}\text { National } \\
\text { Operation } \\
\text { al } \\
\text { Program } \\
\text { me } \\
\text { (PON): } \\
\text { EU + } \\
\text { national } \\
\text { funds }\end{array}$ & $\begin{array}{l}€ 180 \\
\text { million }\end{array}$ & DSO \\
\hline \multirow[b]{2}{*}{ Storage } & $\begin{array}{l}\text { National } \\
\text { and private } \\
\text { funds }\end{array}$ & $\begin{array}{l}€ 200 \\
\text { millions }\end{array}$ & $\begin{array}{l}\text { TSO, DSO } \\
\text { and } \\
\text { consumers }\end{array}$ & \multirow[b]{2}{*}{$\begin{array}{l}\text { Increase } \\
\text { in } \\
\text { network } \\
\text { tariffs }\end{array}$} & \multirow[b]{2}{*}{$\begin{array}{l}€ 160 \\
\text { million }\end{array}$} & \multirow[b]{2}{*}{$\begin{array}{l}\text { TSO and } \\
\text { DSO }\end{array}$} & \multirow{2}{*}{$\begin{array}{l}\text { Increase } \\
\text { in } \\
\text { metering } \\
\text { tariffs } \\
(+2 \% \\
\text { WACC } \\
\text { for } 12 \\
\text { years })\end{array}$} & \multirow[b]{2}{*}{$\begin{array}{l}€ 253 \\
\text { million }\end{array}$} & \multirow[b]{2}{*}{ TSO } \\
\hline & $\begin{array}{l}\text { Low- } \\
\text { interest } \\
\text { loans by } \\
\text { Governme } \\
\text { nt-owned } \\
\text { developme } \\
\text { nt bank }\end{array}$ & $\begin{array}{l}€ 80 \\
\text { millions }\end{array}$ & Consumers & & & & & & \\
\hline Conversion & $\begin{array}{l}\text { Increase in } \\
\text { network } \\
\text { tariffs } \\
\text { (Surcharge } \\
\text { to } \\
\text { electricity } \\
\text { from CHP) }\end{array}$ & $\begin{array}{l}\text { Max } \\
\text { annual } \\
\text { fund of } \\
€ 1.5 \\
\text { billion }\end{array}$ & Generators & $\begin{array}{l}\text { EU, } \\
\text { national } \\
\text { and } \\
\text { private } \\
\text { funds }\end{array}$ & $\begin{array}{l}€ 30 \\
\text { million }\end{array}$ & TSO & - & - & - \\
\hline
\end{tabular}

Source: See Appendix A for a detailed list of analysed projects.

\footnotetext{
${ }^{15}$ See Appendix A for sources on analysed projects.
} 
Although our overview has no claim of being exhaustive due to the difficulty of acquiring data on investments in innovation, what clearly emerges is a lack of investment in ESI. Even investments in ESI-enabling technologies do not seem high enough to keep up with EU decarbonisation targets.

\section{Economic and Policy Barriers}

The lack of investment in ESI can be explained by the existence of different economic and policy barriers to its adoption. While some of these will disappear naturally as technology advances, direct policy actions are required to address most of them.

The first economic barrier is the cost of adopting ESI-enabling technologies. Some of these technologies are capital-intensive in nature, such as CHP. Others are costly because they are at the beginning of their lifecycle and the cost of investment could significantly decrease once their adoption increases, as it is happening with EBs. A high cost of adoption is a serious concern particularly for final users.

The second barrier is the intrinsic risk of these innovative projects, both in term of economic viability of in-development technologies (e.g., P2G) and in terms of consumer acceptance (e.g., DR). The risk-averse nature of network operators can be a strong limiting factor in fostering the adoption of these technologies.

The third barrier is the institutional constraints in incentivising the adoption of innovative technologies when the existing regulatory framework calls for a technology-neutral approach. The Directorate-General for Competition (DG COMP) of the European Commission suggests that incentives to innovation should not favour one technology to another (DG-COMP, 2013). This will allow the market to select the 'best' innovative solution to adopt without further interventions from the regulator (CEER, 2018). However, as noted by DG-COMP (2013) technology-neutrality should not lead to the adoption of cheaper and mature solutions while postponing investments in more expensive but promising technologies.

The fourth barrier is the coordination between grid users (i.e., generators, TSOs, DSOs, retailers, consumers), and especially TSOs and DSOs. For the delivery of a clean and reliable energy system at the lowest total cost, ESI requires grid users to provide the service that minimizes the overall system cost. However, this technology solution may not be optimal for some users, who may thus have a lack of incentive to invest on it. This is particularly true for 
DSOs. The integration of DG has led to higher operational expenditures for DSOs due to the greater complexity arising from managing a two-way system, aside from the capital expenditure of the DG connection. The diffusion of PEVs will make the loads less predictable and will require major investments in the grid. Conversion and storage systems will also enhance the complexity of managing the distribution network. DR and DG contribute to load shaving objectives, but they also reduce the overall electricity demand, thus decreasing operators' revenues.

Aside from this, coordination in itself can be costly as it requires interaction within and between sectors. The problem of coordination is not exclusive to the interactions between different energy systems. With the increasing penetration of PEVs, the integration of electricity and transportation networks is a challenging issue for both energy and transportation regulators. A focal issue is the tariff design and charging mechanisms. In addition, establishing who and how should finance, construct and operate charging infrastructures is an unsolved challenge. The question of whether DSOs should play a role in the roll-out of PEV charging infrastructures is currently being debated across the European Union (E-DSO, 2018).

The fifth barrier is the access to data. Coordination between upstream and downstream grid users within and between networks is facilitated by an efficient communication stream. While smart meters and smart grids can collect data on network status and user consumption, these data need to be accessible in order for new business models to emerge and to allow optimization throughout the energy system. However, the user that controls these data may not have incentives to share them with other grid users. A further problem is related to data ownership, especially on final user's consumptions. Consumers may not wish to disclose detailed data regarding their consumptions and the appliances they have installed as it can be perceived as a privacy intrusion.

The sixth barrier is consumer acceptance. As mentioned the possibility of consumers being against the collection of their data and diffusion of technologies deemed intrusive. However, consumers may also resist to investments in innovation leading to higher tariffs. The risky nature of innovative projects makes so that blindly funding innovation spending is not viable, since this may be costly with respect to the benefits gained from innovation. These investments need to be assessed having in mind potential consumer gains. Furthermore, although integrating RES and DG in an ESI scenario leads to lower system costs, it still requires large investments in the networks with respect to the current situation. This can lead to a resistance from 
consumers to both RES and DG integration and to innovation in the energy networks in case the cost of those technologies is completely passed to them.

The seventh barrier is related to the role of the regulator. The regulator should identify a clear boundary between regulation and the market. For instance, while penetration of electric vehicles significantly impacts DSOs' operation (E-DSO, 2018), there remains ambiguity regarding whether to involve DSOs in the roll-out of PEVs or not. Another example is the different approaches by the European regulators towards allowing DSOs to own and operate storage systems, due to the risk of having a monopolist operating in a potentially competitive market. While in Norway DSOs can own and operate them, in the UK storage is classified as generation and therefore DSOs can own but only third parties can operate them due to unbundling constraints (CEER, 2019). In Italy, the regulator allows DSOs to invest in storage systems, but this investment cannot be recovered through distribution tariffs unless it is justified through a cost-benefit analysis (CEER, 2019). The lack of a clear and uniform policy regarding what network operators are allowed to do can influence the emergence of new players, new business models and the adoption of ESI-enabling technologies.

An eighth barrier is the behaviour of prosumers behind-the-meter. Further diffusion of DG and storage systems can lead to a scenario of increasing independence of prosumers from the grid. These users may rely less and less on the grid as their share of self-consumption raises. By consuming less energy coming from the grid, they would contribute less to maintenance and expansion of the infrastructure. This in turn would cause fewer consumers to sustain the cost of building, maintaining and operating the network, pushing more of them to go off-grid. This self-sustaining cycle could make the cost of the energy system raise substantially for whoever cannot operate DG and storage.

The final policy barrier is whether the European regulators have the resources and disposition to intervene on the whole energy system cohesively. Typically, energy sectors have been regulated separately from one another and regulatory decisions regarding economic activities within each energy network are taken independently. This may lead to overspecialization and a lack of holistic view, which is a strong requirement for ESI to be successful. In particular, this sector-specific approach may deprive investment in those innovative technologies that calls for an integrated view as required within the ESI paradigm. 


\section{Conclusion and Policy Implications}

ESI can be an effective way to integrate RES and DG while providing a reliable and affordable energy system. However, the implementation of this paradigm and the improved coordination between different energy systems requires not only the adoption of innovative technologies, but also a new implementation of policies and regulation. This Section aims at discussing policy interventions needed to enable ESI. To this aim, Table 4 lists the barriers identified in the previous chapter together with potential policy solutions. We discuss in detail each policy solution in the following.

Table 4: Policy solutions to barriers for ESI implementation

\begin{tabular}{|c|c|c|c|c|c|c|c|c|c|}
\hline Proposed Policies & 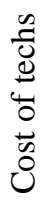 & 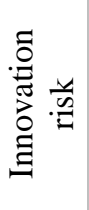 & 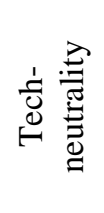 & 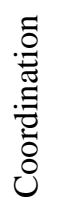 & 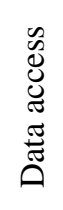 & 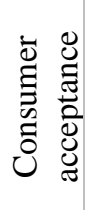 & 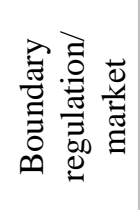 & 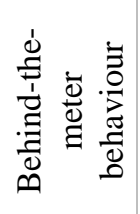 & 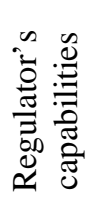 \\
\hline Innovation incentives & $\mathrm{x}$ & $\mathrm{x}$ & $\mathrm{X}$ & & & & & & \\
\hline Drive consumer actions & $\mathrm{x}$ & $\mathrm{x}$ & & & & $\mathrm{x}$ & & & \\
\hline $\begin{array}{l}\text { Foster emergence of new } \\
\text { players }\end{array}$ & $\mathrm{x}$ & $\mathrm{x}$ & & & & & $\mathrm{x}$ & & \\
\hline TSO/DSO adoption & $\mathrm{x}$ & & & & & & $\mathrm{x}$ & & \\
\hline ICT \& data access & & $\mathrm{x}$ & & $\mathrm{x}$ & $\mathrm{x}$ & & & & \\
\hline Incentivise coordination & & & & $\mathrm{x}$ & $\mathrm{x}$ & & $\mathrm{x}$ & & \\
\hline Decoupled revenues & & & & $\mathrm{x}$ & & & & $\mathrm{x}$ & \\
\hline $\begin{array}{l}\text { Cross-sector development } \\
\text { plans }\end{array}$ & $\mathrm{x}$ & & & $\mathrm{x}$ & & $\mathrm{x}$ & & & $\mathrm{x}$ \\
\hline Coordination at the EU level & $\mathrm{x}$ & $\mathrm{x}$ & $\mathrm{x}$ & $\mathrm{x}$ & $\mathrm{x}$ & $\mathrm{x}$ & $\mathrm{x}$ & & $\mathrm{x}$ \\
\hline
\end{tabular}

Innovation incentives. ESI requires investment in new technologies, and network operators are naturally positioned to lead the process. Regulatory frameworks should therefore incentivise investments of network utilities in innovation. The implementation of output-based incentive regulation is well suited for this goal, as it shifts the focus from economic efficiency to an efficient delivery of output measures specified by the regulator. Regulators should recognize that, due to asymmetry of information, firms are better positioned to know the best ways to 
deliver an output, meaning which technology will work best and at a lowest cost. Therefore, firms should be required to take on an active role in determining how to deliver outputs (Ofgem, 2010). On the other hand, clear output specification is necessary to avoid opportunistic behaviour or a focus on the short term which may lead firms to choose sub-optimal investment solutions. Gaining the know-how to properly calibrate outputs will inevitably require a trialand-error approach by regulators. However, looking at countries which are adopting outputbased incentive regulation (e.g., the UK) can provide useful guidance. The adoption of a Totex approach is an important step in incentivising innovation. Traditionally, regulatory frameworks have treated capital (Capex) and operational expenditures (Opex) differently: by adding Capex to the RAB, they introduce a bias to Capex-heavy investments. However, ESI-enabling technologies provide flexibility to the grid: they reduce the need for investments in grid and generation capacity, but they create a more complex grid. Therefore, they cause a raise in Opex which is more than offset by the reduction in Capex. If a bias to Capex is present, firms could still prefer to invest in the more costly Capex-heavy solutions. The Totex approach considers both Capex and Opex, thus eliminating the incentive to favour capital intensive investments. This approach, pioneered by the UK, is being followed by other EU countries such as Italy (AEEGSI, 2017) and, in a narrower scope, France (CRE, 2018). Network innovation needs also to be fostered through specific incentives, as they lower the risk the regulated firm bears. In this regard, the regulator can take two approaches: to fix the revenue allowance and the expected result of the innovation process beforehand, or to fix the revenue allowance for innovation but leave network firms with the freedom to decide how to spend it. The Italian and French national energy authorities take the first approach. In Italy, the regulator chooses which SG projects should be financed and awards them with an extra capital remuneration. In France, the regulator approves or rejects the innovation plan and budget of each network firm for the regulatory period. In the UK, both approaches are used. With the Network Innovation Competition, the regulator decides which projects to finance and by how much. On the other hand, through the Network Innovation Allowance it assigns to each operator an extra allowance that the operator can use to finance innovation projects which do not need regulatory approval. The latter approach might provide a right balance of risk and remuneration at a stage where there is a need to invest a lot in innovation. This allows the regulator to guarantee the affordability of innovation while leaving firms with the flexibility to come up with new solutions. Furthermore, risk of innovation can be substantially reduced through a sharing of results of innovative projects. When investments are financed through regulatory mechanisms to stimulate 
innovation, regulators should impose network operators to disseminate the results of their innovative projects irrespective of failure or success (such an approach is taken both in the UK and in Italy).

Drive consumer actions. Consumers need to play an active role in ESI. Adoption of household level storage systems (e.g., electric batteries) and conversion technologies (e.g., hybrid heat pumps) could be incentivised through tariff-based support mechanisms, like feed-in tariffs for DG, or through government grants or loans. The latter approach has been taken in Germany where the government has provided low-interest loans through its development bank KfW for battery storage units that are installed alongside PV systems. While, up to 2016, KfW has given $60 \mathrm{~m}$ euros in funding, this spurred investment of about $450 \mathrm{~m}$ euros. ${ }^{16}$ Investment from private citizens can play a role in helping these technologies develop to a more mature stage, thus lowering their cost while also reducing the burden for the energy system. The need for such incentives would disappear once the technologies are mature enough, as the savings they provide make up for the investment cost. While consumers benefit from these technologies as a way to perform arbitrage, prosumers would use them to increase their self-consumption rate and be off-grid during peak loads. This can be beneficial to both prosumers (lower final electricity bills) and network operators (lower network costs). Consumer acceptance of more intrusive technologies can also be enhanced through appropriate price signals. DR can be made more attractive should it lead to a lower energy bill. Detailed consumption disclosure could also be conditional on a reduction in the price of consumed energy, or to some other form of monetary incentive (without this exempting from the need to comply with privacy protection rules).

Foster emergence of new players. Aside from consumers, other grid users could benefit from tariff-based support mechanisms. Where markets are still not deemed mature, these mechanisms could help new business models to emerge. Flexibility providers could install storage and conversion systems to provide services to the grid. Through the CHP Act (KWKG 2018), in Germany a surcharge is granted to electricity generated through CHP. This has been used to promote construction and modernisation of cogeneration plants and of heat networks. By considering storage as generation, similar pricing policy as for DG can be adapted to ESS, which implies diverse tariff mechanisms for importing and injecting electricity.

\footnotetext{
${ }^{16}$ See https://www.bmwi.de/Redaktion/EN/Artikel/Energy/funding-programmes-for-energy-storage.html.
} 
TSO/DSO adoption. Equating storage to generation has led most European regulators to forbid TSOs and DSOs to operate storage systems. Indeed, where the context could allow new grid users to provide such service, having a monopolist operating in a competitive market would be detrimental. However, due to energy systems being different from one another due to scale, geography or a variety of other reasons, in some cases a competitive market would not develop. Regulators should under such conditions, allow network operators to own and operate storage and conversion systems. Allowing DSOs and TSOs to own and operate storage can significantly reduce infrastructure costs and the need to build excess capacity (ITRE, 2015). Similarly, operating conversion systems could allow network firms to take advantage of economies of scope. Such a scenario should not require providing firms with any incentive, as investing in such technologies would be advantageous for them due to the overall cost reduction. Allowing this type of investments could be a temporary measure used to increase adoption and lower the cost of these technologies. Once the conditions for a competitive market are mature, network firms could be required to divest (allowing for an adequate remuneration of previously invested capitals and avoiding regulatory opportunism).

ICT \& data access. While ESI entails physical exchanges of energy within and between energy systems, it is mostly data and information exchanges which make the integration possible. Therefore, investments in ICTs in the form of smart grids and smart meters should be incentivised. Data transparency rules and clear third-party access policies could be used to increase coordination among grid users.

Incentivise coordination. However, coordination will also require remunerating the new services that network firms provide to the system. This has been recognized by the Italian regulator, which introduced a mitigation-service fee that the DSO receives from the TSO when it helps limiting the impact of interruptions in the transmission grid by allowing back-feeding in the distribution network through appropriate grid rearrangements (AEEGSI, 2015). Similarly, the TSO pays the DSO for having access to real-time data on the state of the distribution grid, which is then used by the TSO for balancing reasons (CEER, 2018).

Decoupled revenues. ESI requires decoupling network firms' revenues from energy consumption. This is needed to both coordinate grid users and to ensure profitability for distributors which could face increases in costs and reductions in revenues in an ESI scenario. DSOs could be required to connect DGs, conversion and storage systems, while their revenues would be linked to the number of connections provided. Such an approach is used in Germany, 
where DSOs' revenue allowances are adjusted by an expansion factor that takes into account the amount of DG connected. As sales and consumption of energy will increasingly differ, system costs will make up for a higher proportion of the final user's energy bill. The need to provide an affordable energy system for everybody will require prosumers to contribute to the network irrespective of self-consumption rate (Cambini and Soroush, 2019).

Cross-sector development plans. Lowering system costs requires coordinated development plans for network operators. Network firms' investment decisions should take into account the whole energy system to exploit existing synergies. Regulators could either require that network firms do so in their business plans or they could raise (lower) revenue allowances for firms that (do not) do so. Furthermore, innovation incentives could also be conditional on the fact that the innovation provides system benefits. For instance, in the consultations for RIIO-2, the UK's regulator has recognized the need for an integrated approach and is assessing how to deliver it (Ofgem, 2018).

Coordination at the EU level. As the EU has identified ESI as a priority (ENTSO-E and ENTSOG, 2019), there is a need to ensure greater coordination at European level. This could be achieved by giving more leverage to the Agency for the Cooperation of Energy Regulators (ACER), although its prescriptive power would need to be limited to recognize the peculiarities and different demands of each State’s energy system. The EU coordinator would need to engage with relevant stakeholders to identify opportunities to deliver cross-country integration solutions (e.g., North Sea offshore grid integration). It would foster exchanges between regulators, disseminating best practices and helping create regulatory know-how. It would also look at successful pilot projects throughout Europe to identify what is technologically needed by the market and to impose standards for the industry. Granting access to the results of network firms’ innovation projects would reduce risk and prevent duplication of effort.

In our discussion of possible policy interventions to drive ESI we refrain from providing too specific solutions. This follows from recognising that ESI needs to be a bespoke approach that considers the characteristics and needs of the systems. Its adoption and the different barriers that will be encountered may differ from case to case, so will the policies needed to overcome them. In our analysis we provided a menu of possible solutions, with the idea that ESI can be achieved through a proper design of incentives to grid users. 


\section{Reference}

AEEGSI (2015). "Deliberazione 23 dicembre 2015-653/2015/R/EEL - Testo integrato della regolazione output-based del servizio di trasmissione dell'energia elettrica, per il periodo di regolazione 2016-2023".

AEEGSI (2017). “Documento per la consultazione - 683/2017/R/EEL - Applicazione dell'approccio totex nel settore elettrico. Primi orientamenti per l'introduzione di schemi di regolazione incentivante fondati sul controllo complessivo della spesa”.

Agrell, P.J. and Bogetoft, P. (2011). "Smart-Grid Investments, regulation and organization”. CORE Discussion Paper no. 2011/72, Université catholique de Louvain, Louvain-la-Neuve, Belgium.

Ameli, H., Qadrdan, M. and Strbac, G. (2017). “Techno-economic assessment of battery storage and power-to-gas: a whole-system approach”. Energy Procedia, 142, 841-848.

ARegV (2019). "Verordnung über die Anreizregulierung der Energieversorgungsnetze”. Anreizregulierungsverordnung vom 29. Oktober 2007 (BGBl. I S. 2529), die zuletzt durch Artikel 2 des Gesetzes vom 14. März 2019 (BGBl. I S. 333) geändert worden ist.

Atherton, J., Sharma, R. and Salgado, J. (2017). "Techno-economic analysis of energy storage systems for application in wind farms”. Energy, 135, 540-552.

Bauknecht, D. and Brunekreeft, G. (2008). “Distributed Generation and Network Regulation”. in Sioshansi, F.P. (ed), Competitive Electricity Markets: Design, implementation and performance, Oxford: Elsevier, 469-497.

Bauknecht, D. (2011). “Incentive Regulation and Network Innovations”. EUI Working Paper, RSCAS 2011/02, European University Institute, San Domenico di Fiesole, Italy.

Baumann, C., Schuster, R. and Moser, A. (2013). "Economic potential of power-to-gas energy storages”. 10th International Conference on the European Energy Market (EEM), 1-6.

Bloomberg New Energy Finance (2018). “New Energy Outlook 2018”. Bloomberg, London, UK and New York, USA.

BMWi (2018). “Innovations for the Energy Transition - 7th Energy Research Programme of the Federal Government”. Retrieved from Federal Ministry for Economic Affairs and Energy website: https://www.bmwi.de/Redaktion/EN/Publikationen/Energie/7th-energy-research-programme-ofthe-federal-government.html

Brodecki, L., Tomaschek, J., Fahl, U. and Alonso, J. (2014). "Synergies in the integration of energy networks for electricity, gas, heating and cooling”. INSIGHT_E.

Brown, T., Schlachtberger, D., Kies, A., Schramm, S. and Greiner, M. (2018). "Synergies of sector coupling and transmission reinforcement in a cost-optimised, highly renewable European energy system”. Energy, 160, 720-739.

Budny, C., Madlener, R. and Hilgers, C. (2015). "Economic feasibility of pipe storage and underground reservoir storage options for power-to-gas load balancing”. Energy Conversion and Management, 102, 258-266. 
Burlinson, A. and Giulietti, M. (2018). "Non-traditional business models for city-scale energy storage: evidence from UK case studies”. Economia e Politica Industriale, 45(2), 215-242.

Cambini, C. (2016). “Changing Regulatory Approaches”. Nature Energy, 1, September.

Cambini, C., Meletiou, A., Bompard, E. and Masera, M. (2016a). "Market and regulatory factors influencing smart-grid investment in Europe: evidence from pilot projects and implications for reform.” Utilities Policy 40: 36-47.

Cambini, C., Fumagalli, E., and Rondi, L. (2016b). "Incentives to quality and investment: Evidence from electricity distribution in Italy”. Journal of Regulatory Economics, 49(1), 1-32.

Cambini, C. and Soroush, G. (2019). "Designing grid tariffs in the presence of distributed generation”. Utilities Policy, 61.

CEER (2019). "New Services and DSO Involvement”. Council of European Energy Regulators Conclusion Paper, March 2019.

CEER (2018). "Incentives Schemes for Regulating Distribution System Operators, including for innovation”. Council of European Energy Regulators Conclusion Paper, February 2018.

Cheng, M., Sami, S.S. and Wu, J. (2017). "Benefits of using virtual energy storage system for power system frequency response”. Applied Energy, 194, 376-385.

Colmenar-Santos, A., Rosales-Asensio, E., Borge-Diez, D. and Blanes-Peiró, J.-J. (2016). “District heating and cogeneration in the EU-28: Current situation, potential and proposed energy strategy for its generalisation”. Renewable and Sustainable Energy Reviews, 62, 621-639.

Cossent, R., Gomez, T. and Frias, P. (2009). "Towards a Future with Large Penetration of Distributed Generation: Is the Current Regulation of Electricity Distribution Ready? Regulatory Recommendations under a European Perspective.” Energy Policy 37(3): 1145-1155.

Cossent, R., Olmos, L., Gómez, T., Mateo, C. and Frías, P. (2011). "Distribution network costs under different penetration levels of distributed generation”. European Transactions on Electrical Power, 21(6), 1869-1888.

CRE (2018). “Délibération de la Commission de régulation de l'énergie du 14 juin 2018 portant projet de décision sur les tarifs d'utilisation des réseaux publics d'électricité dans les domaines de tension HTA et BT”. Retrieved from https://www.cre.fr/Documents/Deliberations/Decision/Tarifs-dutilisation-des-reseaux-publics-d-electricite-dans-les-domaines-de-tension-HTA-et-BT

de Joode, J., Jansen, J., Van der Welle, A. and Scheepers, M.J.J. (2009). "Increasing penetration of renewable and distributed electricity generation and the need for different network regulation". Energy Policy 37(8): 2907-2915.

de Joode, J., Van der Welle, A. and Jansen, J. (2010). "Distributed generation and the regulation of distribution networks”. InTech, 2010.

DNV GL (2014). “Integration of renewable energy in Europe”. DNV GL, Imperial College London, NERA Economic Consulting.

EC (2015). "Best practices on Renewable Energy Self-consumption”. Communication from the Commission to the European Parliament, the Council, the European Economic and Social Committee and the Committee of the Regions: Delivering a New Deal for Energy Consumers, 
Brussels,

2015.

Available

at:

https://ec.europa.eu/energy/sites/ener/files/documents/1_EN_autre_document_travail_service_par t1_v6.pdf.

EC Directorate-General for Energy (2011). "Standardization Mandate to European Standardisation Organisations (ESOs) to support European Smart Grid deployment”. M/490.

E-DSO (2018). "Smart charging: integrating a large widespread of electric cars in electricity distribution grids”. European Distribution System Operators for Smart Grids, March 2018.

ENA (n.d.). In “’Smarter Networks’ Portal”. Retrieved from http://www.smarternetworks.org/

ENTSO-E and ENTSOG (2019). TYNDP 2020 Scenario Report.

European Commission, (2003). "Directive 2003/54/EC of the European Parliament and of the Council of 26 June 2003 concerning common rules for the internal market in electricity and repealing Directive 96/92/EC.”

European Commission (2009), "Directive 2009/72/EC of the European Parliament and of the Council of 13 July 2009 concerning common rules for the internal market in electricity and repealing Directive 2003/54/EC”, Official Journal of European Union, L211, 55-97.

Elzinga, D. (2011). “Technology Roadmaps - Smart Grids”. IEA, International Energy Agency.

Eurostat (2019). In “Combined Heat and Power (CHP) data 2005-2016”. Retrieved from https://ec.europa.eu/eurostat/web/energy/data

Fernandez, L.P., Roman, T.G.S., Cossent, R., Domingo, C. M. and Frias, P. (2011). “Assessment of the Impact of Plug-in Electric Vehicles on Distribution Networks”. IEEE Transactions on Power Systems, 26(1), 206-213.

Glachant, J.M., Khalfallah, H., Perez, Y., Rious, V. and Saguan, M., (2012). “Implementing Incentive Regulation and Regulatory Alignment with Resource Bounded Regulators”. EUI Working Papers RSCAS 2012/31. European University Institute, San Domenico di Fiesole, Italy.

Gugler, K., Liebensteiner, M. and Schmitt, S. (2017). "Vertical disintegration in the European electricity sector: Empirical evidence on lost synergies”. International Journal of Industrial Organization, 52, 450-478.

IEA (2018). “CO2 emissions from fuel combustion 2018 overview”. International Energy Agency.

ITRE (2015). “Energy Storage: Which Market Designs and Regulatory Incentives Are Needed?”. European Parliament's Committee on Industry, Research and Energy (ITRE) by Policy Department A: Economic and Scientific Policy, October 2015.

Jamasb, T. (2017). “Energy Storage: Friend or Foe of the Networks?”. Nature Energy, 2(6), 5 June.

Jamasb, T and Llorca, M. (2019). "Energy Systems Integration: Economics of a New Paradigm”. Economics of Energy and Environmental Policy, 8(2), 7-28.

Jenkins, J.D. and Pérez-Arriaga, I.J. (2017). "Improved regulatory approaches for the remuneration of electricity distribution utilities with high penetrations of distributed energy resources.” The Energy Journal 38(3): 63-91. 
Joskow, P.L. (2014). "Incentive Regulation in Theory and Practice: Electricity Distribution and Transmission Networks,” NBER Chapters, in: Economic Regulation and Its Reform: What Have We Learned?, pages 291-344, National Bureau of Economic Research, Inc.

Kerr, T. (2008). "Combined heat and power: evaluating the benefits of greater global investment”. Retrieved from IEA, International Energy Agency website: https://www.iea.org/publications/freepublications/publication/chp_report.pdf

KWKG (2018). "Gesetz für die Erhaltung, die Modernisierung und den Ausbau der Kraft-WärmeKopplung". Kraft-Wärme-Kopplungsgesetz vom 21. Dezember 2015 (BGBl. I S. 2498), das zuletzt durch Artikel 2 des Gesetzes vom 17. Dezember 2018 (BGBl. I S. 2549) geändert worden ist.

Leuthold, M. et al. (2015). Batteriespeicher in der Nieder- und Mittelspannungsebene - Anwendungen und Wirtschaftlichkeit sowie Auswirkungen auf die elektrischen Netze, VDE Verband der Elektrotechnik Elektronik Informationstechnik e.V., Berlin.

Li, N. and Hedman, K.W. (2015). "Economic Assessment of Energy Storage in Systems with High Levels of Renewable Resources”. IEEE Transactions on Sustainable Energy, 6(3), 1103-1111.

Lo Schiavo, L., Delfanti, M., Fumagalli, E. and Olivieri, V. (2013). "Changing the regulation for regulating the change: innovation-driven regulatory developments for smart grids, smart metering and e-mobility in Italy”. Energy Policy, 57, 506-517.

Martin Almenta, M., Morrow, D. J., Best, R. J., Fox, B. and Foley, A. M. (2016). “Domestic fridgefreezer load aggregation to support ancillary services”. Renewable Energy, 87, 954-964.

Meeus, L. and Saguan, M., (2011). "Innovating grid regulation to regulate grid innovation: from the Orkney Isles to Kriegers Flak via Italy”. Renewable Energy 36 (6), 1761-1765.

Müller, C. (2011). "New regulatory approaches towards investments: a revision of international experiences”. WIK Diskussionsbeitrag Nr. 356, Wissenschaftliches Institut für Infrastruktur und Kommunikationsdienste GmbH, Bad Honnef, Germany.

Nykamp, S., Andor, M. and Hurink, J.H. (2012). "Standard' incentive regulation hinders the integration of renewable energy generation”. Energy Policy, 47, 222-237.

Ofgem (2010). "Handbook for implementing the RIIO model”. Retrieved from https://www.ofgem.gov.uk/publications-and-updates/handbook-implementing-riio-model

Ofgem (2017). “The network innovation review: our policy decision”. Retrieved from https://www.ofgem.gov.uk/system/files/docs/2017/03/the_network_innovation_review_our_polic y_decision.pdf

Ofgem (2018). "RIIO-2 sector specific methodology consultation". Retrieved from https://www.ofgem.gov.uk/publications-and-updates/riio-2-sector-specific-methodologyconsultation

Ofgem (2019). In "Electricity system flexibility". Retrieved from https://www.ofgem.gov.uk/electricity/retail-market/market-review-and-reform/smarter-marketsprogramme/electricity-system-flexibility.

Peças Lopes, J.A., Hatziargyriou, N., Mutale, J., Djapic, P. and Jenkins, N. (2007). "Integrating Distributed Generation into Electric Power Systems: A Review of Drivers, Challenges and Opportunities.” Electric Power Systems Research 77(9): 1189-1203. 
Pöyry, and Ricardo. (2016). "An independent evaluation of the LCNF”. Retrieved from https://www.ofgem.gov.uk/system/files/docs/2016/11/evaluation_of_the_lcnf_0.pdf

Prüggler, N. and Bremberger, C. (2011). "Grid regulation in Austria: smart grids incentives or disincentives?”. Elektrotechnik und Informationstechnik, 128 (10), 336-341.

Sandia (2013). "Market and Policy Barriers to Energy Storage Deployment: A Study for the Energy Storage Systems Program”. Sandia National Laboratories, September 2013.

Schiebahn, S., Grube, T., Robinius, M., Tietze, V., Kumar, B. and Stolten, D. (2015). "Power to gas: Technological overview, systems analysis and economic assessment for a case study in Germany”. International Journal of Hydrogen Energy, 40(12), 4285-4294.

Strbac, G. (2002). “Impact of Dispersed Generation on Distribution Systems: A European Perspective.” Power Engineering Society Winter Meeting 1: 118-120.

World Energy Council (2016). “World energy resources 2016”. World Energy Council, London, UK. 
Appendix A. List of Projects and Sources

\begin{tabular}{|c|c|c|}
\hline Project Name & Source & Country \\
\hline NIC and NIA projects & http://www.smarternetworks.org/ & UK \\
\hline FREEDOM & http://www.smarternetworks.org/ & UK \\
\hline SINTEG & https://www.bmwi.de/ & Germany \\
\hline $\begin{array}{l}\text { Energy Storage Funding } \\
\text { Initiative - R\&D and } \\
\text { demonstration of storage } \\
\text { technologies } \\
\end{array}$ & https://www.bmwi.de/; https://forschung-energiespeicher.info/ & Germany \\
\hline $\begin{array}{c}\text { KfW Banks - loans for } \\
\text { EBs }\end{array}$ & https://www.bmwi.de/ & Germany \\
\hline CHP Act & $\begin{array}{l}\text { Gesetz für die Erhaltung, die Modernisierung und den Ausbau } \\
\text { der Kraft-Wärme-Kopplung. Kraft-Wärme-Kopplungsgesetz } \\
\text { vom 21. Dezember } 2015 \text { (BGBl. I S. 2498), das zuletzt durch } \\
\text { Artikel } 2 \text { des Gesetzes vom 17. Dezember } 2018 \text { (BGBl. I S. } \\
\text { 2549) geändert worden ist. }\end{array}$ & Germany \\
\hline WindNODE & https://www.sinteg.de/; https://www.windnode.de/ & Germany \\
\hline SMILE & https://smile-smartgrids.fr/ & France \\
\hline FlexGrid & http://www.flexgrid.fr/ & France \\
\hline SG pilot projects & http://www.smartgrids-cre.fr/ & France \\
\hline $\begin{array}{l}11 \text { pilot projects in } \\
\text { isolated networks }\end{array}$ & $\begin{array}{l}\text { Délibération de la Commission de régulation de l'énergie du } 4 \\
\text { octobre } 2018 \text { portant décision sur la compensation des projets } \\
\text { de stockage centralisé dans les zones non interconnectées dans } \\
\text { le cadre du guichet d’octobre } 2017 .\end{array}$ & France \\
\hline RINGO & $\begin{array}{l}\text { Délibération de la Commission de Régulation de l’Energie du } \\
7 \text { décembre } 2017 \text { portant approbation du programme } \\
\text { d'investissements de RTE pour } 2018 .\end{array}$ & France \\
\hline Jupiter 1000 & https://www.jupiter1000.eu/ & France \\
\hline SG pilot projects & https://www.arera.it/ & Italy \\
\hline $\begin{array}{l}\text { e-Distribuzione - SG } \\
\text { projects }\end{array}$ & https://www.e-distribuzione.it/; http://www.ponic.gov.it/ & Italy \\
\hline $\begin{array}{c}\text { e-Distribuzione -Open } \\
\text { Meter project }\end{array}$ & $\begin{array}{l}\text { Deliberazione } 6 \text { aprile } 2017 \text { - 222/2017/R/EEL - Sistemi di } \\
\text { smart metering di seconda generazione (2G): decisione sul } \\
\text { piano di messa in servizio e sulla richiesta di ammissione al } \\
\text { riconoscimento degli investimenti in regime specifico di e- } \\
\text { distribuzione S.p.a. }\end{array}$ & Italy \\
\hline $\begin{array}{l}\text { Terna S.p.A. - Project Lab } \\
\text { and Large Scale Energy } \\
\text { Storage pilot projects }\end{array}$ & http://www.terna.it/ & Italy \\
\hline
\end{tabular}

